\title{
Global variants of COVID-19: Current understanding
}

Roy $\mathrm{B}^{1 *}$, Dhillon $\mathrm{JK}^{2}$, Habib $\mathrm{N}^{3}$, Pugazhandhi $\mathrm{B}^{4}$

\section{*Corresponding author:}

Dr. Bedanta Roy,

Senior Lecturer, Department of Physiology, Faculty of Medicine, Quest International University, Ipoh, Perak, Malaysia

Email: bedanta.roy@gmail.com $\underline{\text { ORCID }}$

\section{Information about the article:}

Received: Jun 4, 2021

Accepted: Jun 29, 2021

Published online: July 11, 2021

\section{Cite this article:}

Roy B, Dhillon JK, Habib N, Pugazhandhi B. Global variants of COVID-19: Current understanding. Journal of Biomedical Sciences. 2021;8(1):8-11

\section{Publisher}

Nepal Health Research Society, Bahundhara -6, Gokarnesowor Municipality, Kathmandu, Nepal eISSN 2382-5545, ISSN 2676-1343 (Print)

(C) The Author(s). 2021

Content licensing: CC BY 4.0

\begin{abstract}
Background

SARS-CoV-2 is an RNA virus that undergoes mutation producing a variety of strains. Mutagens include UV radiation, metals, and endogenous components of organisms. Each strain is specific in terms of virulence, immune response in the body and efficacy of the vaccines.
\end{abstract}

\section{Conclusion}

Researchers need to gather data and collaborate with global organizations to learn about the newly evolving strains. Information about the mutations and variants are inevitable in understanding virus transmission and developing vaccines to end the COVID-19 pandemic.

\section{Keywords}

COVID-19, SARS-CoV-2, strains, variant, Variants of Concern 


\section{Background}

Coronaviruses (CoV) are a family of single-stranded RNA viruses that can transmit infections human to humans (HCoV) documented over 50 years. Coronavirus infectious disease 2019 (COVID-19), was initially reported as the Wuhan Coronavirus or 2019 novel coronavirus, bleeding humanity since December 2019 [1, 2]. At the end of 2019, hospitals in Wuhan, China, reported 4 cases of respiratory illness "pneumonia of an unknown etiology" by surveillance which later emerged as a COVID-19 outbreak [3]. At the present date (June 23, 2021), COVID-19 cases continue to increase with several different mutated variants. According to WHO, the confirmed number of cases of COVID-19 is 178503429 with a death toll of 3872457 [4].

Mutations in the viral genome sequence give birth to different variants. Environmental mutagens include UV radiation, metal ions, and endogenous components of organisms that changed the genetic structure of the SARSCoV-2 from time to time [5]. Coronavirus is an RNA virus that evolves and changes gradually [6]. WHO took the lead role with the researchers of national and international authorities to identify and assess the changes of transmission pattern of SARS-CoV-2, clinical presentation and severity, or their influence on public health and social measures (PHSM). WHO established a close monitoring network to detect "signals" of potential Variants of Concern (VOCs) or Variants of Interest (VOIs), assessing the risk factors concerning public health [Table-1] [4]. Four strains were identified as VOCs by WHO, namely Alpha, Beta, Gamma and Delta.

The Alpha strain (B.1.1.7), which originated from the UK, has accounted for an increase from $3 \%$ of cases in October 2020 to $96 \%$ of cases by February of the following year, resulting in a third wave across the country. B.1.1.7 gradually dominated in the US because of its high transmission rate and lethality, which is $30-70$ percent more than the original strain found in Wuhan, China.

The Beta strain (B.1.351) was first spotted in South Africa in May 2020, which was only announced in December and was said to affect younger age groups compared with previous variants. Since then, the presence of the strain is noticed in 80 countries. E484K mutation makes this strain deadly as it escapes the immune system and the prime cause of the third wave of Coronavirus in South Africa [79].

The Gamma strain (P.1) surfaced in Manaus, Brazil, in November 2020, responsible for two waves of Coronavirus. Data from the patients revealed twice transmissibility of this Gamma strain compared with previous strains. This variant drove a deadly second wave as only 54 to 79 percent protection was observed $[8,9]$.

As of June 21, 2021, WHO reports that the highly contagious Delta variant (B.1.617.2) is the fastest and fittest coronavirus strain yet, affecting the most vulnerable people, especially in areas with low COVID-19 vaccination rates. Delta variant, which was first identified in India, can be more lethal because it is $60 \%$ more transmissible and [10] higher risk of secondary attack rate $[11,12]$.

Delta variant eventually affects the most vulnerable individuals who would succumb to the disease and potentially die [13]. The Delta variant, an existing variant of concern, has driven the deadly second wave of infections this summer in India [14].

According to WHO, the Delta variant currently identified in 92 countries, spreading infections [15]. Centres for Disease Control and Prevention raised the alarm saying that $10 \%$ of all new cases in the United States are due to the Delta variant and become dominant. Similar trends followed in The United Kingdom, where the delta variant gradually took over the first detected native alpha variant and responsible for more than $60 \%$ of fresh infections in the U.K. [13].

A spike protein mutation in the Delta coronavirus resulted a new variant termed Delta Plus. The Delta COVID-19 variant (B.1.617.2) was first identified in India in October 2020, later found in other countries. Variants of Concern (VOCs) was declared on May 1, 2021. This new variant, referred to as Delta with K417N mutation, has been found in several other countries, including Britain, the United States, Canada, Japan, Nepal, Poland, Portugal, Russia, Switzerland and Turkey. A majority of these reported cases are from the US, Britain and Portugal [16].

\begin{tabular}{|c|c|c|c|c|c|}
\hline $\begin{array}{l}\text { WHO } \\
\text { label }\end{array}$ & Pango lineage & GISAID clade & $\begin{array}{l}\text { Nextstrain } \\
\text { clade }\end{array}$ & Earliest documented samples & Date of designation \\
\hline \multicolumn{6}{|c|}{ Variants of Concern (VOCs) } \\
\hline Alpha & B.1.1.7 & $\begin{array}{l}\text { GRY (formerly } \\
\text { GR/501Y.V1) }\end{array}$ & 20I/501Y.V1 & United Kingdom, Sep-2020 & 18-Dec-2020 \\
\hline Beta & B.1.351 & GH/501Y.V2 & 20H/501Y.V2 & South Africa, May-2020 & 18-Dec-2020 \\
\hline Gamma & P.1 & GR/501Y.V3 & 20J/501Y.V3 & Brazil, Nov-2020 & 11-Jan-2021 \\
\hline Delta & B.1.617.2 & G/452R.V3 & 21A/S:478K & India, Oct-2020 & $\begin{array}{l}\text { VOI: 4-Apr-2021 VOC: } 11- \\
\text { May-2021 }\end{array}$ \\
\hline \multicolumn{6}{|c|}{ Variants of Interest (VOIs) } \\
\hline Epsilon & B.1.427/ B.1.429 & GH/452R.V1 & 20C/S.452R & United States of America, Mar- 2020 & 5-Mar-2021 \\
\hline Zeta & P.2 & GR & 20B/S.484K & Brazil, Apr-2020 & 17-Mar-2021 \\
\hline Eta & B.1.525 & G/484K.V3 & 20A/S484K & Multiple countries, Dec-2020 & 17-Mar-2021 \\
\hline Theta & P.3 & GR & 20B/S:265C & Philippines, Jan-2021 & 24-Mar-2021 \\
\hline Iota & B.1.526 & GH & 20C/S:484K & United States of America, Nov- 2020 & 24-Mar-2021 \\
\hline Карра & B.1.617.1 & G/452R.V3 & 21A/S:154K & India, Oct-2020 & 4-Apr-2021 \\
\hline
\end{tabular}




\section{Conclusion}

Countries all over the world gird themselves against the new coronavirus variants, and researchers need to gather data and collaborate with global organizations to make them aware of greater threats. Information abouts the mutations and variants are inevitable to understand the virus transmission and develop vaccines to end the COVID-19 pandemic.

\section{Abbreviation}

Coronavirus disease 2019 (COVID-19), Severe acute respiratory syndrome coronavirus 2 (SARS-CoV-2), Variants of Concern (VOCs), Variants of Interest (VOIs)

\section{Authors' contribution}

a. Study planning: BR, NH, PB

b. Manuscript writing: BR, JKD, NH

c. Manuscript revision: BR, JKD, NH, PB

d. Final approval: BR, JKD, NH, PB

e. Agreement to be accountable for all aspects of the work: $\mathrm{BR}, \mathrm{JKD}, \mathrm{NH}, \mathrm{PB}$

\section{Funding}

There was no funding for this work.

\section{Availability of data and materials}

All data and materials available as part of the article, and no additional source data are required.

\section{Competing interests}

There is no conflict of interest for any author of this manuscript.

\section{Publisher's Note}

NHRS remains neutral with regard to jurisdictional claims in published maps and institutional affiliations.

The publisher shall not be legally responsible for any types of loss, actions, claims, proceedings, demand or costs or damages whatsoever or howsoever caused arising directly or indirectly in connection with or arising out of the use of this material.

\section{Author information}

${ }^{1}$ Dr. Bedanta Roy, Senior Lecturer, Department of Physiology, Faculty of Medicine, Quest International University, Ipoh, Perak, Malaysia ORCID

${ }^{2}$ Jaysheena Kaur Dhillon, Biomedical student, Faculty of Medicine, Quest International University, Ipoh, Perak, Malaysia ORCID

${ }^{3}$ Dr. Nasrin Habib, Senior Lecturer, Department of Physiology, Faculty of Medicine, Quest International University, Ipoh, Perak, Malaysia ORCID
${ }^{4}$ Mr. Pugazhandhi B, Research fellow, Melaka Manipal Medical College (MMMC), Manipal Campus, Madhav Nagar, Eshwar Nagar, Manipal, Karnataka 576104, India. ORCID

\section{References}

1. Li X, Geng $\mathrm{M}$, Peng $\mathrm{Y}$, Meng L, Lu S. Molecular immune pathogenesis and diagnosis of COVID-19. J Pharm Anal. 2020;10(2):102-108.

2. Roy B. COVID-19 and neurological complications: Is it alarming?. Journal of Biomedical Sciences. 2020;7(2):52-3.

3. Tan W, Zhao X, Ma X, Wang W, Niu P, Xu W et al. A Novel Coronavirus Genome Identified in a Cluster of Pneumonia Cases - Wuhan, China 2019-2020. China CDC Weekly. 2020;2(4):61- 62.

4. COVID-19 Weekly Epidemiological Update. Edition 43, published 8 June 2021. Available from:

https://reliefweb.int/sites/reliefweb.int/files/reso urces/20210608_Weekly_Epi_Update_43.pdf

5. Sanjuan R, Domingo-Calap P. Mechanisms of viral mutation. Cell Mol Life Sci. 2016;73(23):4433-48.

6. Ray S, Bollinger R. (2021, February 22). New Variants of Coronavirus: What You Should Know. Johns Hopkins Medicine. [Accessed on 1/07/2021] Available from: https://www.hopkinsmedicine.org/health/condit ions-and-diseases/coronavirus/a-new-strain-ofcoronavirus-what-you-should-know

7. Coronavirus Disease 2019 (COVID-19). (2020, February 11). Centers for Disease Control and Prevention. [Accessed on 1/07/2021] Available from: https://www.cdc.gov/coronavirus/2019ncov/variants/variant.html

8. Tracking SARS-CoV-2 variants. [Accessed on 1/07/2021] Available from: World Health Organization.

https://www.who.int/en/activities/trackingSARS-CoV-2-variants/

9. Duncan, G. (2021, June 9). What are the COVID-19 variants and how do Alpha, Beta and Delta differ? The National. [Accessed on 1/07/2021] Available from: https://www.thenationalnews.com/uae/health/w hat-are-the-covid-19-variants-and-how-doalpha-beta-and-delta-differ-1.1236702

10. Callaway E. Delta coronavirus variant: scientists brace for impact. [Accessed on 25/06/21]. Available online from: 
https://www.nature.com/articles/d41586-02101696-3

11. Cherian S, Potdar V, Jadhav S, Gupta N, Das S, Das M. Convergent evolution of SARS-CoV-2 spike mutations, L452R, E484Q and P681R, in the second wave of COVID-19 in Maharashtra, India.

bioRxiv. https://doi.org/10.1101/2021.04.22.440932

12. Public Health England. SARS-CoV-2 Variants of Concern and Variants under Investigation in England Technical Briefing 14.; June 3, 2021. [Accessed on 1/07/2021] Available from: https://assets.publishing.service.gov.uk/govern ment/uploads/system/uploads/attachment_data/f ile/991343/Variants_of_Concern_VOC_Techni cal_Briefing_14.pdf

13. Lovelace B. WHO says delta is the fastest and fittest Covid variant and will "pick off" most vulnerable. CNBC. June 21, 2021. [Accessed on 1/07/2021] Available from: https://www.cnbc.com/2021/06/21/covid-deltawho-says-variant-is-the-fastest-and-fittest-andwill-pick-off-most-vulnerable-.html

14. Biswas S. Delta plus: Scientists say too early to tell risk of COVID-19 variant. BBC News. June $23^{\text {rd }}$ 2021. Accessed on 1/07/2021] Available from: https://www.bbc.com/news/world-asiaindia-57564560

15. Pelzel K. In rare in-person interview, World Health Organization expert Maria Van Kerkhove tells Today News Africa why people die from COVID-19, even as cases rise in Africa. Today News Africa. June 20, 2021. [Accessed on 1/07/2021] Available from: https://todaynewsafrica.com/in-rare-in-personinterview-world-health-organization-expertmaria-van-kerkhove-tells-today-news-africawhy-people-die-from-covid-19-even-as-casesrise-in-africa/

16. Dasgupta D. Delta Plus, a potentially deadlier coronavirus variant, causing concern in India. The Straits Times. June 23, 2021 [Accessed on 1/07/2021] Available from: https://www.straitstimes.com/asia/southasia/india-says-new-covid-variant-is-a-concernindia-declares-delta-plus-a-variant-of 